\title{
Differential Expression of Small Heat Shock Proteins in Reactive Astrocytes after Focal Ischemia: Possible Role of $\beta$-Adrenergic Receptor
}

\author{
Tetsuya Imura, ${ }^{1}$ Shun Shimohama, ${ }^{1}$ Masaaki Sato, ${ }^{2}$ Hiroyuki Nishikawa, ${ }^{2}$ Kenya Madono,, ${ }^{2}$ Akinori Akaike, ${ }^{2}$ \\ and Jun Kimura ${ }^{1}$ \\ 'Department of Neurology, Graduate School of Medicine, and 2Department of Pharmacology, Graduate School of \\ Pharmaceutical Science, Kyoto University, Kyoto 606-8507, Japan
}

Small heat shock proteins (sHSPs), a family of HSPs, are known to accumulate in the CNS, mainly in astrocytes, in several pathological conditions such as Alexander's disease, Alzheimer's disease, and Creutzfeldt-Jakob disease. SHSPs may act not only as molecular chaperones, protecting against various stress stimuli, but may also play a physiological role in regulating cell differentiation and proliferation. In the present study, we have demonstrated that transient focal ischemia in rats dramatically induced HSP27 but not $\alpha$ B-crystallin $(\alpha \mathrm{BC})$, both of which are members of SHSPs, in reactive astrocytes. In contrast, in vitro chemical ischemic stress induced both HSP27 and $\alpha \mathrm{BC}$ in cultured glial cells to the same extent. Dibutyryl

Small heat shock proteins (sHSPs), a family of HSPs, are categorized by their molecular masses ranging from 15 to $30 \mathrm{kDa}$. Although sHSP in mammalian cells was initially identified as a component of a single protein (HSP27, also known as HSP25 or HSP28), recent studies have revealed that $\alpha$ B-crystallin ( $\alpha \mathrm{BC})$, a component of the vertebrate eye lens protein, is also a member of the sHSP family (Klemenz et al., 1991). HSP27 and $\alpha \mathrm{BC}$ form oligomeric structures (Augusteyn and Koretz, 1987; Arrigo et al., 1988) that are modified by phosphorylation, reducing the multimeric size (Benndorf et al., 1994; Lavoie et al., 1995). Phosphorylation of HSP27 is increased in response to various stimuli such as serum, calcium ionophore, and a set of growth factors or cytokines (Welch, 1985; Saklatvala et al., 1991).

In the CNS, sHSPs are predominantly localized in glial cells. Marked induction of both HSP27 and $\alpha \mathrm{BC}$ in cultured astrocytes was observed in response to stress stimuli (Head et al., 1994). The deposition of HSP27 and $\alpha \mathrm{BC}$ was found mainly in astrocytes and oligodendrocytes associated with various neurological diseases such as Alexander's disease (Iwaki et al., 1993), CreutzfeldtJakob disease (Renkawek et al., 1992), multiple sclerosis (van Noort et al., 1995), and Alzheimer's disease (Shinohara et al.,

\footnotetext{
Received March 4, 1999; revised Aug. 2, 1999; accepted Sept. 1, 1999.

This work was supported by Grants-in-Aid for Scientific Research from the Ministry of Education, Science, Sports, and Culture of Japan and grants from the Ministry of Welfare of Japan and the Smoking Research Foundation for Scientific Research.

Correspondence should be addressed to Dr. Shimohama, Department of Neurology, Graduate School of Medicine, Kyoto University, 54 Shogoin-Kawaharacho, Sakyo-ku, Kyoto 606-8507, Japan. E-mail: i53367@sakura.kudpc.kyoto-u.ac.jp. Copyright (C) 1999 Society for Neuroscience $0270-6474 / 99 / 199768-12 \$ 05.00 / 0$
}

cAMP (dBcAMP) and isoproterenol, a $\beta$-adrenergic receptor $(\beta A R)$ agonist, enhanced HSP27 expression but suppressed $\alpha \mathrm{BC}$, and changed the shape of the cells to a stellate form. $\mathrm{dBcAMP}$ and isoproterenol inhibited cell proliferation under normal conditions. An increase in $\beta A R$-like immunoreactivity was also observed in reactive astrocytes in vivo. These results, together with recent findings that $\beta A R$ plays an important role in glial scar formation in vivo, raise the possibility that $\beta A R$ activation modulates sHSP expression after focal ischemia and is involved in the transformation of astrocytes to their reactive form.

Key words: small heat shock proteins; ischemia; reactive astrocytes; $\beta$-adrenergic receptor; glia; cell differentiation

1993; Renkawek et al., 1994a).

The function of sHSPs is still unclear. sHSPs are thought to act as molecular chaperones in the maintenance of the native conformation of cytosolic proteins, allowing cells to survive under stress conditions (Jakob et al., 1993). Furthermore, recent studies have shown that sHSPs may also play a physiological role. The expression of sHSP is developmentally regulated in several organisms (Arrigo, 1995). In mammalian cells, an increase in sHSP was observed during differentiation (Shakoori et al., 1992; Spector et al., 1992), and the constitutive expression of sHSP inhibited Fas/APO-1-mediated apoptosis and cell proliferation (Mehlen et al., 1996, 1997). These results raise the hypothesis that sHSPs could regulate cell differentiation and proliferation under both physiological and pathological conditions. In response to brain injury, astrocytes extend numerous processes to form scar tissues-a process called reactive gliosis. The transformation of "resting" astrocytes to their "reactive" form is characterized by hypertrophy, stellated shape, and an increase in glial fibrillary acidic protein (GFAP) expression. Although little is known about the precise mechanism of the transformation in response to pathological insult, recent studies have revealed that $\beta$-adrenergic receptor $(\beta \mathrm{AR})$ plays an important role in developing reactive gliosis (Sutin and Griffith, 1993; Mantyh et al., 1995).

In the present study, we demonstrated the differential expression of the two sHSPs, HSP27 and $\alpha \mathrm{BC}$, in reactive astrocytes after transient focal ischemia, although both sHSPs were induced simultaneously in cultured glial cells exposed to ischemic stress. We hypothesized that additional factors besides ischemia modulated the expression of sHSPs in vivo and investigated the potential role of $\beta \mathrm{AR}$ in the regulation of sHSP expression and the transformation of astrocytes to their reactive form. 


\section{MATERIALS AND METHODS}

Induction of focal ischemia. Male Wistar rats weighing 280-350 gm were purchased from Japan SLC (Kyoto, Japan). Animals were treated in accordance with the guidelines published in the National Institutes of Health guide for the Care and Use of Laboratory Animals. Focal cerebral ischemia was produced by intraluminal nylon thread introduction (Nagasawa and Kogure, 1989). Briefly, the animals were anesthetized with a gas mixture of $1 \%$ halothane, $30 \%$ oxygen, and $70 \%$ nitrous oxide. The common carotid artery (CCA), internal carotid artery (ICA), and external carotid artery (ECA) were exposed by dissection, and a 19 mm length of 4-0 nylon thread precoated with silicon was inserted from the lumen of the ECA into the ICA as far as the proximal end using a globular stopper. Then, the origin of the middle cerebral artery (MCA) was occluded by a silicon-coated embolus. Anesthesia was discontinued, and the development of hemiparesis with upper limb dominance was used as the criteria for ischemic insult. After $2 \mathrm{hr}$ of MCA occlusion, the animals were reanesthetized, and the embolus was removed to allow reperfusion of the ischemic area via the anterior and posterior communicating arteries. Body temperature during surgery was maintained at $37-37.5^{\circ} \mathrm{C}$ using a heating pad and a lamp.

Preparation of brain extracts. Animals were decapitated at various time points $(2,4,24,48,96$, and $168 \mathrm{hr}$ after ischemia), and the brains were rapidly removed. Ischemic hemispheres were homogenized in buffer A [50 mM Tris-HCl, $5 \mathrm{~mm}$ EDTA, $10 \mathrm{~mm}$ EGTA, 0.3\% (w/v) 2-mercaptoethanol, $1 \mathrm{~mm}$ phenylmethylsulfonylfluoride, $0.5 \mathrm{~mm}$ diisopropylfluorophosphate, $10 \mu \mathrm{g} / \mathrm{ml}$ aprotinin, $5 \mu \mathrm{g} / \mathrm{ml}$ pepstatin A, 5 $\mu \mathrm{g} / \mathrm{ml}$ leupeptin, $5 \mathrm{~mm}$ benzamidine, $0.1 \mathrm{~mm}$ orthovanadate, and $1 \mathrm{~mm}$ $\left(\mathrm{NH}_{4}\right)_{6} \mathrm{Mo}_{7} \mathrm{O}_{24}, \mathrm{pH}$ 7.5]. Each homogenate was sonicated for $30 \mathrm{sec}$ and centrifuged at $1000 \times g$ for $10 \mathrm{~min}$, and the pellet was discarded. Then, the supernatant was centrifuged at 100,000 $\times g$ for $60 \mathrm{~min}$, the pellet was collected as the particulate fraction, and the supernatant was collected as the soluble fraction. All procedures were performed at $4^{\circ} \mathrm{C}$. Protein concentrations were determined by the method of Bradford (1976). The samples were kept frozen at $-80^{\circ} \mathrm{C}$ until assay.

Immunoblotting. Protein samples were diluted with sample buffer $(50$ mu Tris-HCl, pH 6.8, 2\% SDS, 2\% 2-mercaptoethanol, 5\% glycerol, $1 \%$ $\mathrm{NP}-40$, and $0.01 \%$ bromophenol blue) and denatured at $95^{\circ} \mathrm{C}$ for $5 \mathrm{~min}$. Samples containing equal amounts of protein $(20 \mu \mathrm{g})$ were electrophoresed on polyacrylamide gels $(8-16 \%)$ in the presence of SDS. Semiquantitative immunoblotting was performed by transferring the proteins to polyvinylidene difluoride microporous membrane, blocking with $5 \%$ nonfat dry milk in $10 \mathrm{~mm}$ PBS containing $0.1 \%$ Tween 20 (PBS-T), and incubating overnight at $4^{\circ} \mathrm{C}$ in the primary antibodies [anti- $\alpha \mathrm{BC}$ antibody (Chemicon, Temecula, CA) diluted 1:3000; anti-HSP25 antibody (StressGen, Victoria, British Columbia, Canada) diluted 1:2000; and anti-Gprotein-coupled receptor kinase 2 (GRK2) antibody (Santa Cruz Biotechnology, Santa Cruz, CA) diluted 1:4000 in 4\% bovine serum albumin (BSA) in PBS-T]. The blots were then washed in PBS-T and incubated with a horseradish peroxidase-conjugated goat anti-rabbit IgG (Amersham) in PBS-T for $1 \mathrm{hr}$ at room temperature. The specific reaction was visualized using the enhanced chemiluminescence (ECL) method (Amersham) and analyzed by quantitative densitometry using a computerized image analysis program (NIH Image 1.51).

Immunohistochemistry. The brains were perfusion-fixed with $4 \%$ paraformaldehyde in $0.1 \mathrm{M}$ phosphate buffer, $\mathrm{pH} 7.4$, under pentobarbital anesthesia $(70 \mathrm{mg} / \mathrm{kg}$, i.p.). The brains were then removed and post-fixed in the same fixative for $6 \mathrm{hr}$. Frozen sections $(16 \mu \mathrm{m}$, coronal) were immunostained with the anti-HSP25 antibody (1:250), with the anti- $\alpha \mathrm{BC}$ antibody (1:500), with the anti- $\beta_{1}$ AR antibody (1:300; Santa Cruz Biotechnology), or with the anti- $\beta_{2}$ AR antibody (1:300; Santa Cruz Biotechnology). Briefly, the sections were preincubated with 5\% BSA for $1 \mathrm{hr}$ and then incubated with the primary antibodies overnight at $4^{\circ} \mathrm{C}$. After washes, the sections were incubated with a biotinylated secondary goat antibody against rabbit $\operatorname{IgG}(1: 1000)$ for $1 \mathrm{hr}$ at room temperature, followed by incubation with avidin-biotin-peroxidase complex (ABC immunoperoxidase kit; Vector Laboratories, Burlingame, CA) for $1 \mathrm{hr}$ at room temperature. After three washes, the sections were reacted with $3,3^{\prime}$-diaminobenzidine and $0.001 \%$ hydrogen peroxide in $10 \mathrm{~mm}$ Tris$\mathrm{HCl}$ buffer. For double-fluorescence immunolabeling, the sections were coincubated in a mixture of mouse anti-GFAP antibody (Boehringer Mannheim, Mannheim, Germany) and the primary antibody overnight at $4^{\circ} \mathrm{C}$ followed by the coincubation in a mixed solution of 1:200 fluorescein (FITC)-conjugated goat anti-mouse IgG and 1:150 rhodamine (TRITC)conjugated goat anti-rabbit IgG. Immunohistochemical staining with
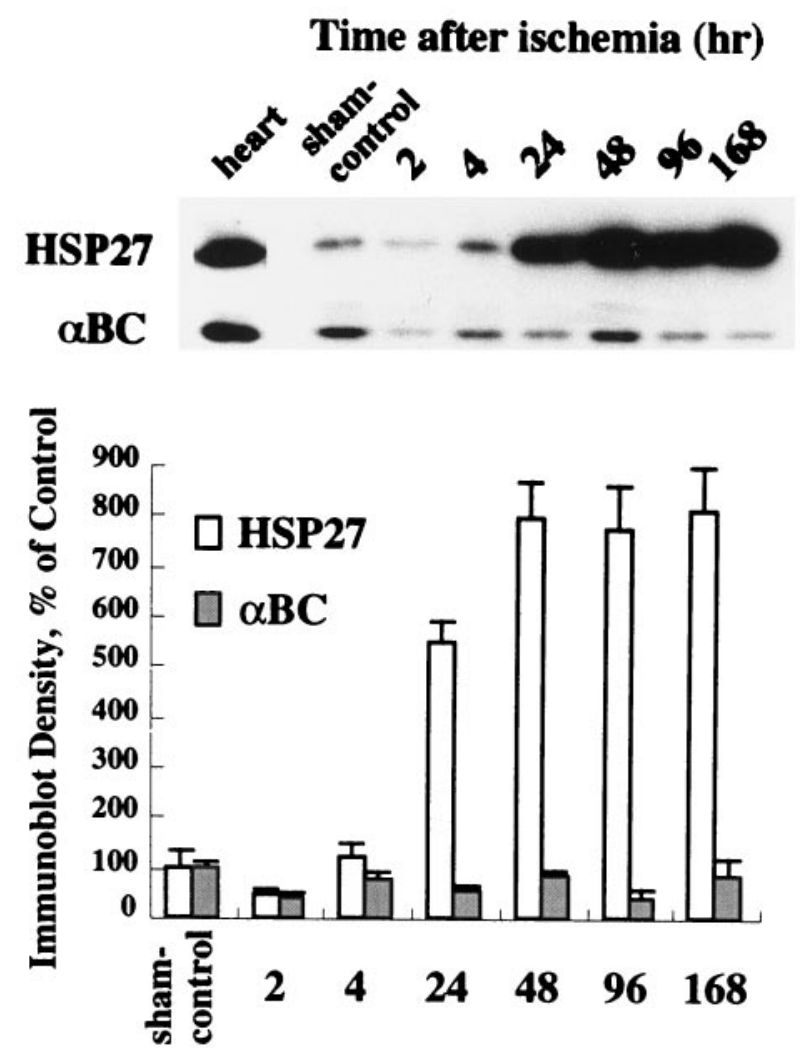

Time after ischemia (hr)

Figure 1. Time course of sHSP expression after focal ischemia. Equal amounts of proteins $(20 \mu \mathrm{g})$ from sham-control or ischemic hemispheres at different time points after ischemia were assayed by immunoblotting using the anti-HSP25 or anti- $\alpha \mathrm{BC}$ antibody. The top panel shows the typical blots of both sHSPs, and the bottom panel shows the results of the densitometric analysis. The marked induction of HSP27 expression was observed continuously from 24 to $168 \mathrm{hr}$ after ischemia. In contrast, the expression of $\alpha \mathrm{BC}$ was not significantly changed and remained at low levels. Data represent mean $\pm \operatorname{SEM}(n=3)$.

FITC-conjugated isolectin B4 from Griffonia simplicifolia seeds (Sigma, St. Louis, MO) was also performed to identify microglia.

Two-dimensional gel electrophoresis. The first dimension of gel electrophoresis was performed using an immobilized $\mathrm{pH}$ gradient gel (immobilized dry strip gel, $\mathrm{pH}$ 4-7, $18 \mathrm{~cm}$; Pharmacia, Uppsala, Sweden) with a horizontal electrophoresis apparatus (Multiphor II; Pharmacia) according to the method described by Gorg et al. (1988). Protein samples were diluted with sample buffer $(50 \mathrm{~mm}$ Tris- $\mathrm{HCl}, \mathrm{pH}$ 6.8, $4 \mathrm{M}$ urea, $0.5 \%$ 2-mercaptoethanol, 5\% glycerol, $1 \%$ NP-40, and $0.01 \%$ bromophenol blue). The sample solution was applied on the anodic side of the gel and run according to the manufacturer's instructions. The second dimension of gel electrophoresis was carried out on a $15 \%$ running gel $(20 \times 20 \times$ $0.1 \mathrm{~cm})$ in the presence of SDS. The separated isoforms of HSP27 were identified by immunoblotting with ECL.

Cell culture and induction of chemical ischemia. Highly enriched astroglial primary cultures were prepared by the method of McCarthy and de Vellis (1980) with minor modifications. In brief, forebrain cortices of newborn Wistar rat pups $(<1 \mathrm{~d})$ were dissected, and the meninges and pia matter were carefully removed. The tissue was trypsinized, mechanically triturated, and plated in tissue culture flasks. Cultures were grown at $37^{\circ} \mathrm{C}$ in a humidified atmosphere with $5 \% \mathrm{CO}_{2}$ in DMEM supplemented with $10 \%$ fetal bovine serum (FBS), $2 \mathrm{~mm}$ glutamine, and penicillin at $100 \mathrm{U} / \mathrm{ml}$ and streptomycin at $100 \mu \mathrm{g} / \mathrm{ml}$. When the cells reached confluence after 12-14 d, the flasks were shaken at $250 \mathrm{rpm}$ for $24 \mathrm{hr}$ to remove nonadherent cells. The remaining cells were replated, and the experiments were performed after 10-14 d. Immunocytochem- 

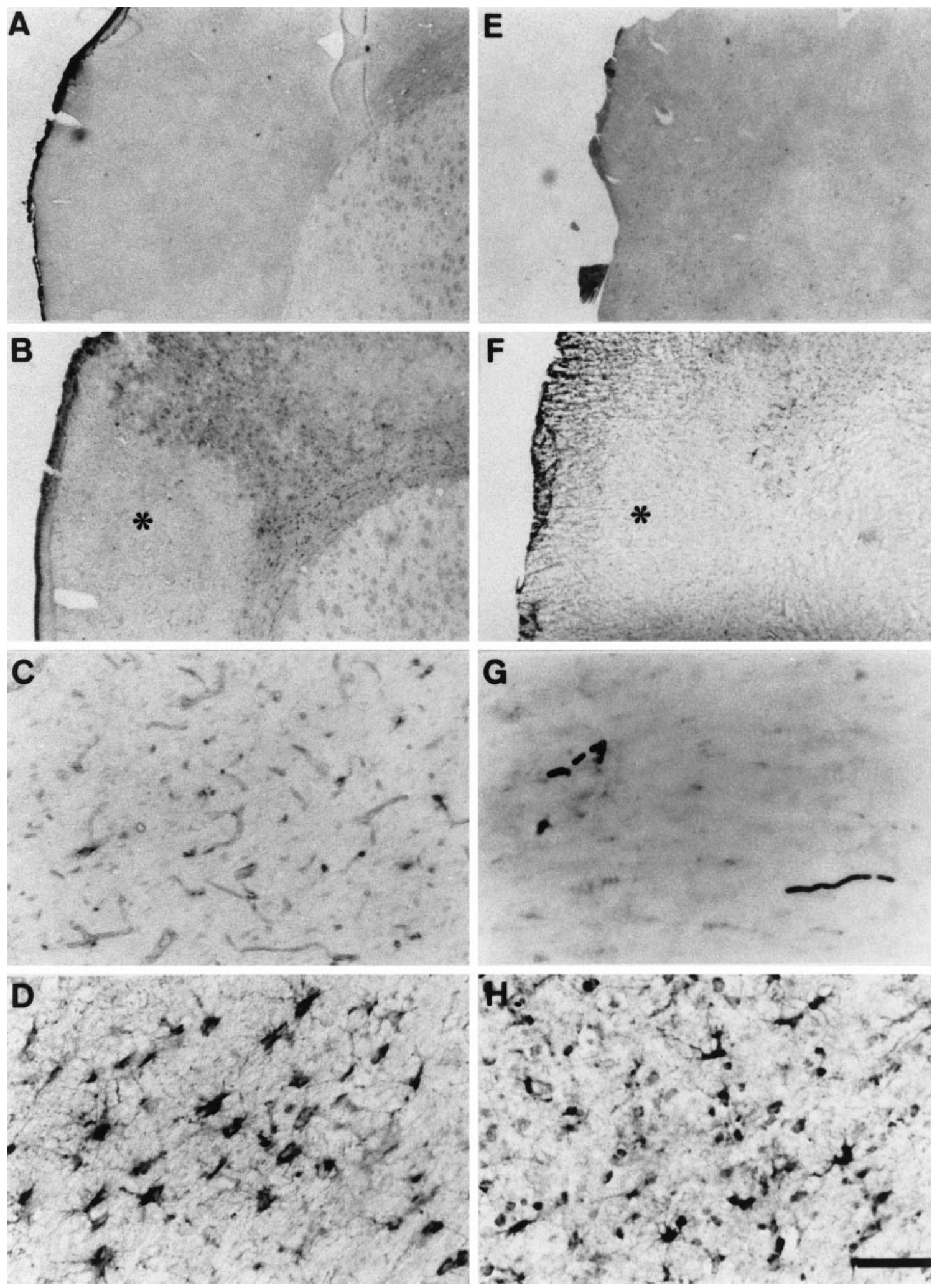

Figure 2. Localization of sHSPs in the rat brain. $A$, Control brain sections showed no HSP27 immunoreactivity. $B$, Intense HSP27 immunostaining was observed surrounding the infarct lesion (asterisk) at $48 \mathrm{hr}$ after ischemia. $C$, Microvessels in the ischemic center were weakly stained with HSP27. $D$, HSP27-positive cells diffusely distributed in the ischemic hemisphere had large cell bodies and numerous processes. $E$, $\alpha \mathrm{BC}$ immunoreactivity in the controls. $\alpha \mathrm{BC}$-positive cells were observed in the deep white matter, the internal capsule, the corpus callosum, and the cortical layers. $F$, $\alpha \mathrm{BC}$ immunoreactivity was also slightly increased surrounding the infarct lesion (asterisk), but was minimal compared with HSP27. $G, \alpha \mathrm{BC}$-positive cells in the corpus callosum in the controls. The shape and the location of the cells was characteristic of oligodendrocytes. $H$, Some process-bearing cells surrounding the infarct lesion also showed $\alpha \mathrm{BC}$ immunostaining in the ischemic brain sections. The number of $\alpha \mathrm{BC}$-positive cells, however, was much less than that of HSP27-positive cells. Scale bar (in $H$ ): $A, B, E, F, 500 \mu \mathrm{m} ; C, 200 \mu \mathrm{m} ; D, G, H, 100 \mu \mathrm{m}$. 

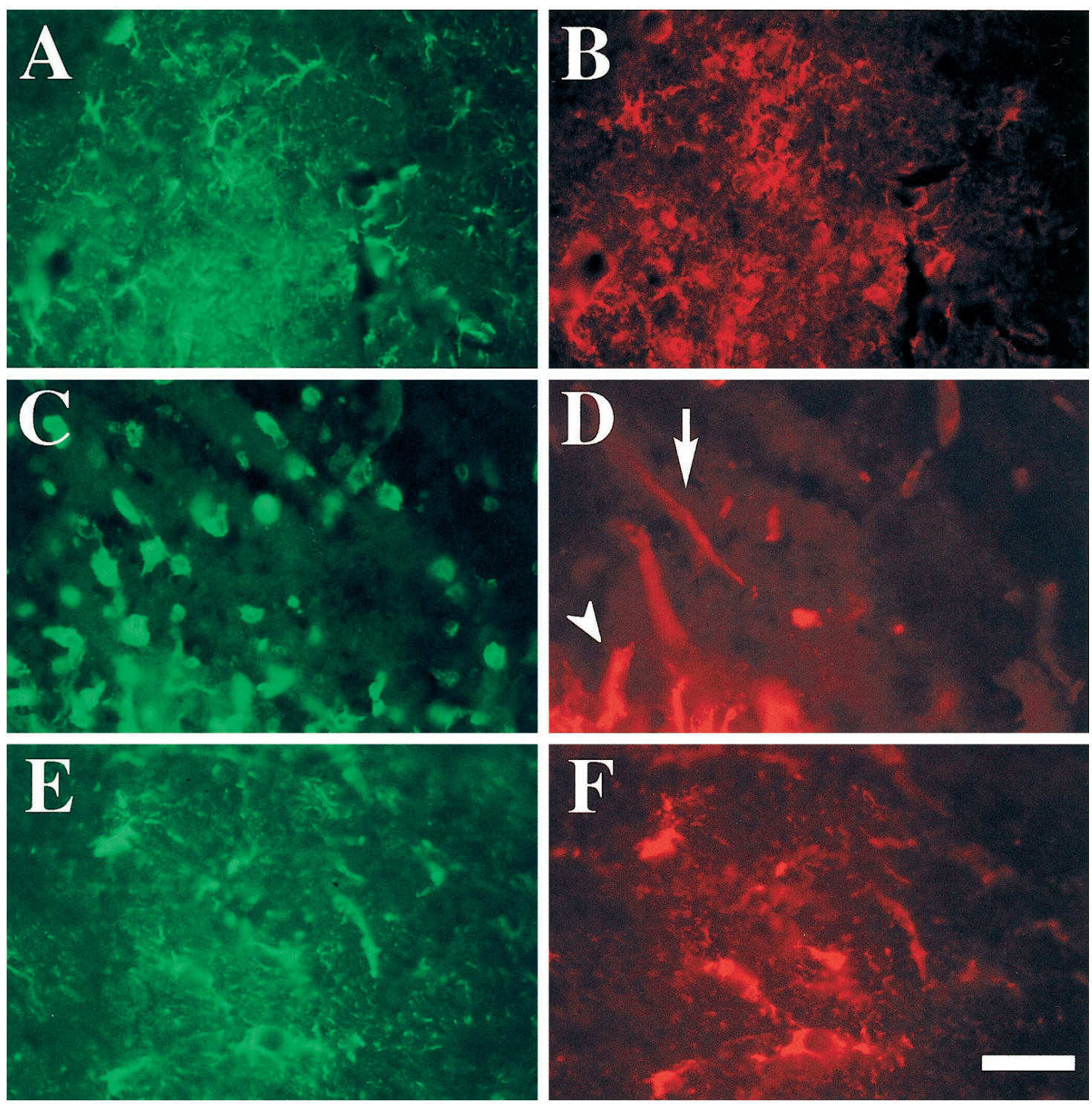

Figure 3. The predominant localization of sHSPs in reactive astrocytes after focal ischemia. Double-fluorescence immunolabeling for GFAP ( $A$, $E$; FITC), isolectin B4 (C; FITC), HSP27 ( $B, D$; TRITC), and $\alpha \mathrm{BC}$ ( $F$; TRITC). HSP27-positive cells widely distributed in the ischemic hemisphere corresponded to GFAP-positive cells $(A, B)$. Microglial cells had no HSP27 immunoreactivity, whereas microvessels in the ischemic center (arrow) and astrocytes in the vicinity of the lesion (arrowhead) were HSP27-positive $(C, D) . \alpha$ BC-positive cells appearing in the peri-infarct area were also GFAP-positive $(E, F)$. Scale bar (in $F$ ): $A, B, 200 \mu \mathrm{m} ; C-F, 100 \mu \mathrm{m}$.

ical characterization showed $>95 \%$ of the cells stained positively for the astrocytic marker GFAP. Rat C6 glioma cells obtained from the American Type Culture Collection (Rockville, MD) were cultured in DMEM with $10 \%$ FBS and used for the same experiments. When cells reached $80 \%$ confluency, they were exposed to chemical ischemic stress. Cells were washed with PBS once and then incubated in chemical ischemic buffer $(10 \mathrm{~mm}$ sodium azide and $10 \mathrm{~mm}$ 2-deoxyglucose in HEPESbuffered saline (in $\mathrm{mM}$ ): $120 \mathrm{NaCl}, 5 \mathrm{KCl}, 0.62 \mathrm{MgSO}_{4}, 1.8 \mathrm{CaCl}_{2}$, and 10 HEPES, pH 7.4). Sodium azide, an inhibitor of oxidative phosphorylation, was used to induce chemical anoxia, and 2-deoxyglucose is known to inhibit glycolysis. Exposure to $10 \mathrm{~mm}$ sodium azide or $10 \mathrm{~mm}$ 2-deoxyglucose for $<1 \mathrm{hr}$ has been shown previously to induce the massive death of cultured neurons (Vornov, 1995; Varming et al., 1996). After $1 \mathrm{hr}$ (cultured astrocytes) or $2 \mathrm{hr}$ (C6 cells) of treatment, cells were washed with PBS twice and then incubated in the standard culture medium. After $24 \mathrm{hr}$ of recovery, cells were washed with PBS twice, scraped, and lysed with buffer A containing $1 \%$ NP-40. The lysates were centrifuged at $20,000 \times g$ for $30 \mathrm{~min}$, and the supernatants were collected to identify HSP27 and $\alpha \mathrm{BC}$ by immunoblotting with ECL. Cultures were also fixed in $4 \%$ paraformaldehyde for $20 \mathrm{~min}$ followed by incubation with the primary antibodies. sHSPs were then visualized using the ABC method and 3,3-diaminobenzidine.

Proliferation and survival assay. Cell proliferation was measured by the MTT assay. The amount of the blue formazan produced from the tetrazolium salt [3-(4,5-dimethylthiazol-2-yl)-2,5-diphenyltetrazoliumbromide(MTT)] is proportional to the number of viable cells (Mosmann, 1983). Cells were seeded in 24 multiwell plates $\left(5 \times 10^{3}\right.$ cells per well) in the standard culture medium. After $24 \mathrm{hr}$, the culture medium was replaced by DMEM-10\% FBS with either $1 \mathrm{mM}$ dibutyryl cAMP (dBcAMP) or $10 \mu \mathrm{M}$ isoproterenol. Cells were incubated for another $6 \mathrm{~d}$ with one media change (cultured astrocytes) or 3 d (C6 cells). After replacement with the standard culture medium, $100 \mu \mathrm{l} \mathrm{MTT}(5 \mu \mathrm{g} / \mu \mathrm{l}$ in PBS) was added followed by incubation for $4 \mathrm{hr}$ at $37^{\circ} \mathrm{C}$. The reaction was stopped by the addition of $1 \mathrm{ml}$ isopropanol/40 $\mathrm{mm} \mathrm{HCl}$ to each well, and the blue formazan product was resolved by gentle shaking. The optical density was measured at $540 \mathrm{~nm}$. Cell viability was determined by trypan blue exclusion assay. The cells were incubated with $0.5 \%$ trypan blue solution for $5 \mathrm{~min}$, and $>200$ cells were counted from the randomly selected fields. The results were shown as percentages of viable cells (cells that exclude trypan blue) in the total cell population. 


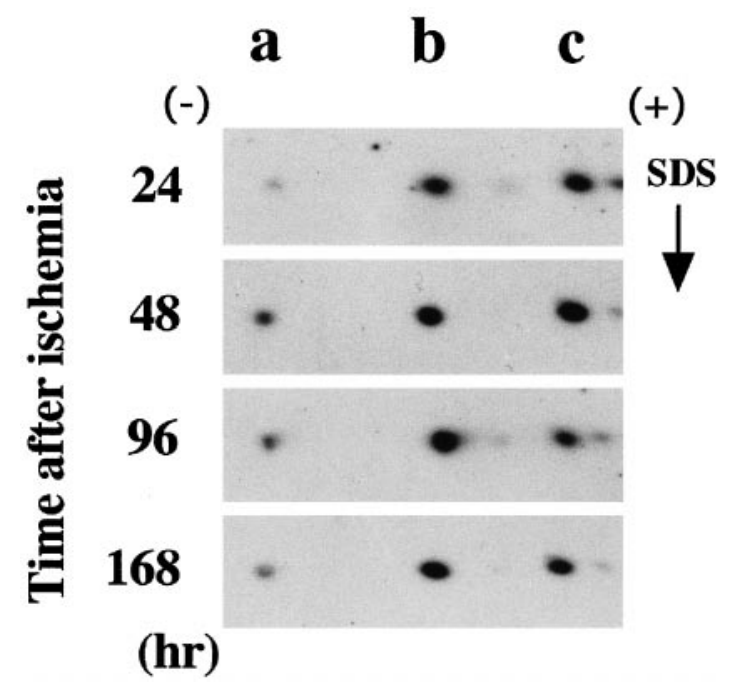

Figure 4. Two-dimensional immunoblotting of HSP27 after focal ischemia. Tissue extracts from ischemic hemispheres were separated by twodimensional gel electrophoresis followed by immunoblotting with the anti-HSP25 antibody. The acidic (+) and basic (-) sides of the gels are indicated. All three isoforms, HSP27a (PI 6.5), HSP27b (PI 6.0), and HSP27c (PI 5.7), could be detected. Both HSP27b, a monophosphorylated isoform, and HSP27c, a biphosphorylated isoform, appeared to be predominant during the time period studied, whereas HSP27a, a nonphosphorylated isoform, was only weakly detected. The results shown are representative of two experiments in each of three independent animals. The ratios $\mathrm{b} / \mathrm{a}, \mathrm{c} / \mathrm{a}$, and $\mathrm{c} / \mathrm{b}$ were not significantly changed during the time studied (data not shown).

\section{RESULTS}

\section{Expression and localization of sHSPs after focal ischemia}

The basal expression of HSP27 was relatively low in the cerebral hemispheres of sham control animals compared to that in the heart. In physiological conditions, heart has been shown to express high levels of both HSP27 and $\alpha \mathrm{BC}$ (Lutsch et al., 1997). After the induction of ischemia, the expression of HSP27 increased dramatically. The induction of HSP27 was observed from $24 \mathrm{hr}$ after ischemia, reaching a maximum at $48 \mathrm{hr}$ and remaining at high levels for $7 \mathrm{~d}$ (Fig. 1). HSP27 expression in the contralateral hemisphere also increased, but at a much reduced level compared to the ischemic side (data not shown). The basal expression of $\alpha \mathrm{BC}$ was also low compared with the heart. Unlike HSP27, $\alpha$ BC expression remained at virtually steady levels after ischemia, and no significant change was observed at any time point studied.

Control brain sections showed no HSP27 immunoreactivity except for faint background staining (Fig. 2A). From 24 to $168 \mathrm{hr}$ after ischemia, intense HSP27 immunostaining was observed surrounding the infarct lesion, and HSP27-positive cells surrounding the lesion had large cell bodies and numerous processes (Fig. 2B,D). Double immunostaining showed that HSP27-positive cells were also GFAP-positive, suggesting that the majority of HSP27-positive cells were reactive astrocytes (Fig. 3A,B). HSP27positive reactive astrocytes were also widely distributed throughout the entire ischemic hemisphere, including both the cortical layers and the deep white matter. Neuropil was also stained for HSP27. Microvessels in the ischemic center were also weakly stained (Fig. 2C). Virtually no neuron was HSP27-positive. Microglial cells, identified by lectin staining, were diffusely distrib- uted in the ischemic center, but HSP27-positive microglia were barely detected (Fig. 3C,D). $\alpha \mathrm{BC}$ immunoreactivity in sham control and ischemic brain sections was also investigated. The majority of $\alpha \mathrm{BC}$-positive cells in the controls were located in the deep white matter, the internal capsule, the corpus callosum, and the cortical layers, with a cell shape and location characteristic of oligodendrocytes (Fig. 2E,G), as described in an earlier report (Iwaki et al., 1992). $\alpha \mathrm{BC}$ immunoreactivity was also slightly increased surrounding the infarct lesion, but was minimal compared with that of HSP27 (Fig. 2F). Double immunostaining revealed that $\alpha \mathrm{BC}$-positive cells in the peri-infarct area were also reactive astrocytes (Fig. 3E,F). The number of $\alpha \mathrm{BC}$-positive reactive astrocytes, however, was much lower than that of HSP27positive cells, and the location was restricted to the border zone of the infarct (Fig. 2F,H).

\section{Analysis of HSP27 phosphorylation after focal ischemia}

HSP27 has at least three isoforms with distinct isoelectric points: HSP27a, HSP27b, and HSP27c. HSP27a is a basic isoform that is not phosphorylated, whereas HSP27b and HSP27c are more acidic isoforms phosphorylated on serine residues (Arrigo and Welch, 1987; Landry et al., 1991). Two-dimensional gel electrophoresis followed by immunoblotting with an anti-HSP25 antibody demonstrated three spots corresponding to the three isoforms of HSP27. Although the ratios b/a, c/a, and $c / b$ were sometimes variable during the time points analyzed, the changes were not statistically significant. The reproducible result obtained was that HSP27b and HSP27c were predominant, whereas HSP27a was poorly detected from 24 to $168 \mathrm{hr}$ after ischemia (Fig. 4).

\section{Modulation of sHSP expression in glial cells by BAR activation}

The basal expression of both HSP27 and $\alpha \mathrm{BC}$ in C6 cells was undetectable. Chemical ischemic stress ( $10 \mathrm{~mm}$ sodium azide and $10 \mathrm{~mm}$ 2-deoxyglucose for $2 \mathrm{hr}$ ) induced both sHSPs to the same extent. dBcAMP enhanced chemical ischemia-induced HSP27 expression but suppressed $\alpha \mathrm{BC}$ expression. Isoproterenol, a $\beta \mathrm{AR}$ agonist, also increased HSP27 expression, but the suppressive effect on $\alpha \mathrm{BC}$ expression was not apparent. Neither dBcAMP nor isoproterenol affected the expression of sHSPs in C6 cells without stress (data not shown). Propranolol, a $\beta$ AR antagonist, could reverse the effect of isoproterenol, whereas propranolol alone had no effect on chemical ischemia-induced sHSP expression (data not shown). Primary astrocytes under standard culture conditions expressed both HSP27 and $\alpha \mathrm{BC}$ at quite high levels, which was different from both in vivo astrocytes and C6 cells. Chemical ischemia increased both sHSPs simultaneously, and both dBcAMP and isoproterenol changed sHSP expression in the same way as in $\mathrm{C} 6$ cells, although the suppression of $\alpha \mathrm{BC}$ by isoproterenol was more potent than $\mathrm{dBcAMP}$ in primary astrocytes. The same change in sHSP expression was observed in the presence of either $\mathrm{dBcAMP}$ or isoproterenol in the absence of chemical ischemia (Fig. 5). The effect of isoproterenol was also antagonized by propranolol in primary astrocytes (data not shown).

Immunocytochemical examination showed that astrocytes were lightly stained for both HSP27 and $\alpha \mathrm{BC}$ under standard culture conditions (data not shown), and chemical ischemia increased both HSP27 and $\alpha \mathrm{BC}$ immunoreactivity with no distinct morphological change. Both sHSPs were diffusely distributed in the cytoplasm. C6 cells, in which sHSP immunoreactivity was ordi- 
(A)

\section{$<$ C6 cells >}

\section{< Astrocytes >}

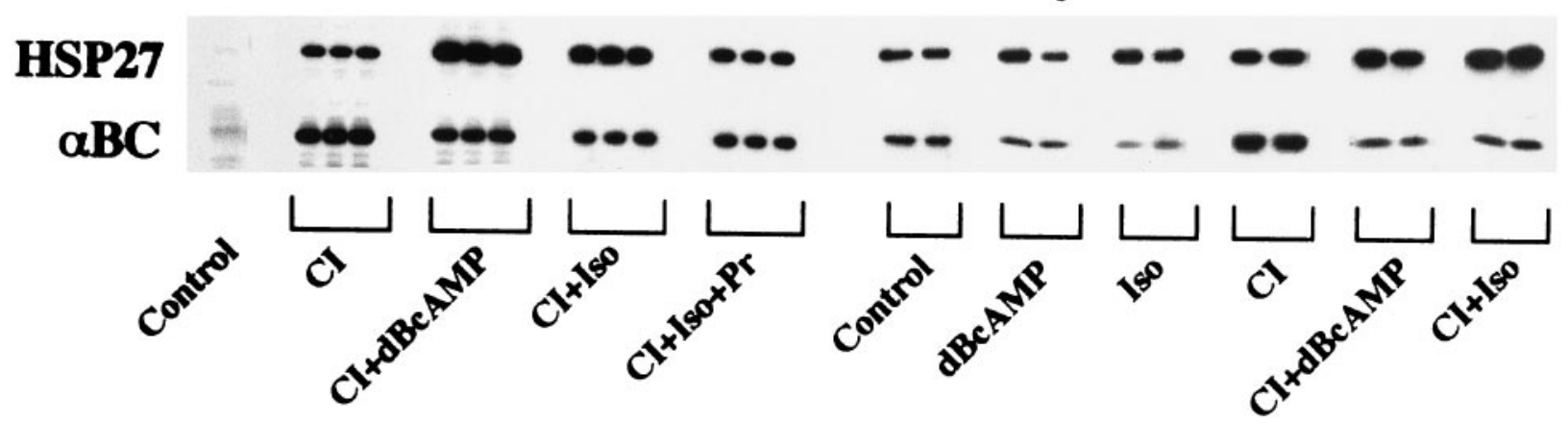

(B)

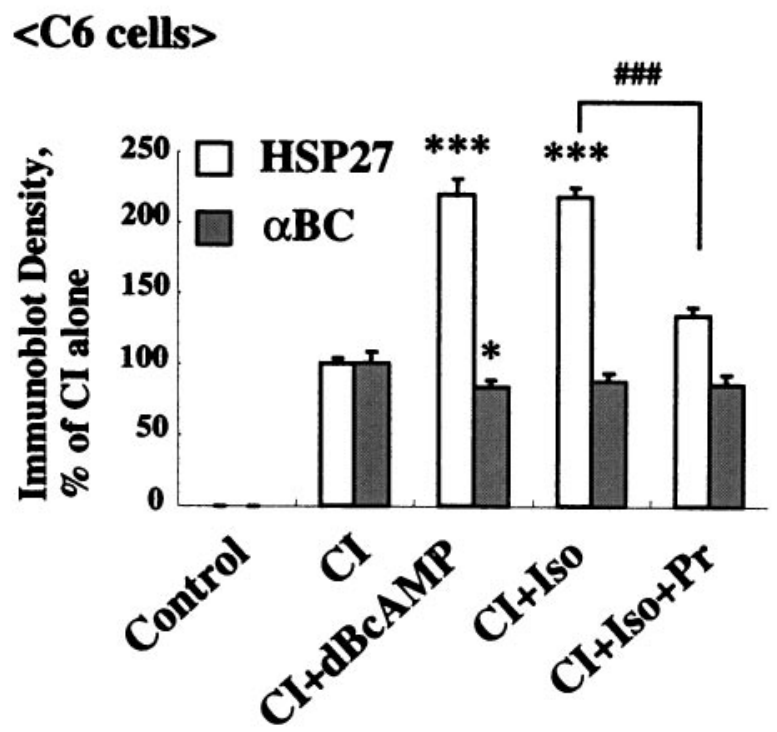

<Astrocytes>

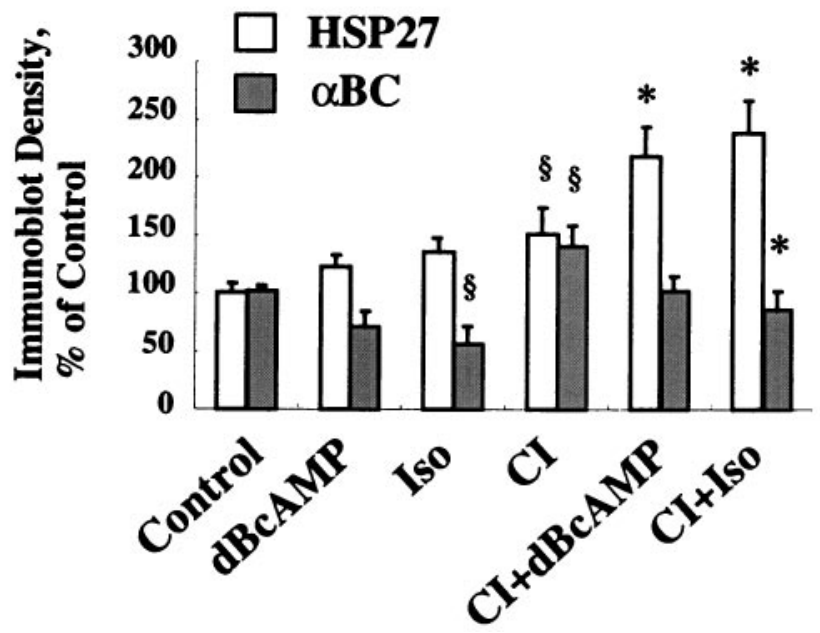

Figure 5. Accumulation of cAMP modulated sHSP expression in cultured glial cells. Both C6 cells and primary astrocytes were exposed to chemical ischemia $(C I)$ in the presence of $1 \mathrm{~mm} \mathrm{dBcAMP}$ or $10 \mu \mathrm{M}$ isoproterenol (Iso), a $\beta \mathrm{AR}$ agonist. After $24 \mathrm{hr}$ of recovery, equal amounts of cell extracts $(20 \mu \mathrm{g})$ were assayed by immunoblotting $(A)$, and densitometric analysis was performed for quantification $(B)$. CI increased the expression of both HSP27 and $\alpha \mathrm{BC}$ to the same extent, and treatment with either dBcAMP or Iso enhanced HSP27 expression but suppressed $\alpha \mathrm{BC}$. The same change in sHSP expression in response to treatment with $\mathrm{dBcAMP}$ or Iso was also observed in primary astrocytes without CI. A $10 \mu \mathrm{M}$ concentration of propranolol $(P r)$, a $\beta$ AR antagonist, reversed the effects of Iso. Data represent mean \pm SEM $(n=6) .{ }^{8} p<0.05$ versus control; ${ }^{*} p<0.05 ; * * * p<0.001$

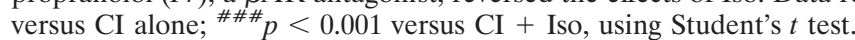

narily absent, also expressed both sHSPs after chemical ischemia. The presence of isoproterenol increased the immunoreactivity of HSP27, whereas $\alpha \mathrm{BC}$ immunoreactivity was slightly decreased and changed the morphology of glial cells. The majority of HSP27-positive cells extended several processes and changed to a stellate form (Fig. 6). The presence of $\mathrm{dBcAMP}$ resulted in the same changes resulting from exposure to isoproterenol (data not shown).

\section{Translocation of $\beta A R$ kinase in the early phase of ischemia}

The agonist-bound form of $\beta \mathrm{AR}$ is phosphorylated by $\beta \mathrm{AR}$ kinase ( $\beta$ ARK), which belongs to a family of GRKs (Benovic et al., 1989). $\beta A R K$ is transiently translocated from the cytosol to the plasma membrane in response to agonist stimulation (Strasser et al., 1986). $\beta A R K$ has two isoforms, $\beta A R K 1$ (GRK2) and $\beta A R K 2$ (GRK3), with $\beta$ ARK1 being the predominant isoform in the CNS (Arriza et al., 1992). Immunoblot analysis demonstrated that $\beta A R K 1$ was abundantly expressed in brains compared with other tissues (data not shown). $\beta$ ARK1 was distributed mainly in the soluble fraction in controls, although it was also identified in the particulate fraction. At $2 \mathrm{hr}$ after ischemia, the $\beta$ ARK levels were significantly decreased in the soluble fraction and increased in the particulate fraction (Fig. 7), suggesting the translocation of $\beta A R K$ from the soluble to the particulate fraction.

\section{$\beta A R-l i k e$ immunoreactivity in reactive astrocytes}

$\beta_{1} \mathrm{AR}$ - and $\beta_{2} \mathrm{AR}$-like immunoreactivity in sham control and ischemic brain sections was investigated. Both $\beta_{1} \mathrm{AR}-$ and $\beta_{2} \mathrm{AR}-$ like immunoreactivities in the controls were predominantly local- 


\section{HSP27 $\alpha B C$}

\section{C6 cells}

\section{CI+Iso}

\section{Astrocytes}

\section{CI}

\section{CI+Iso}
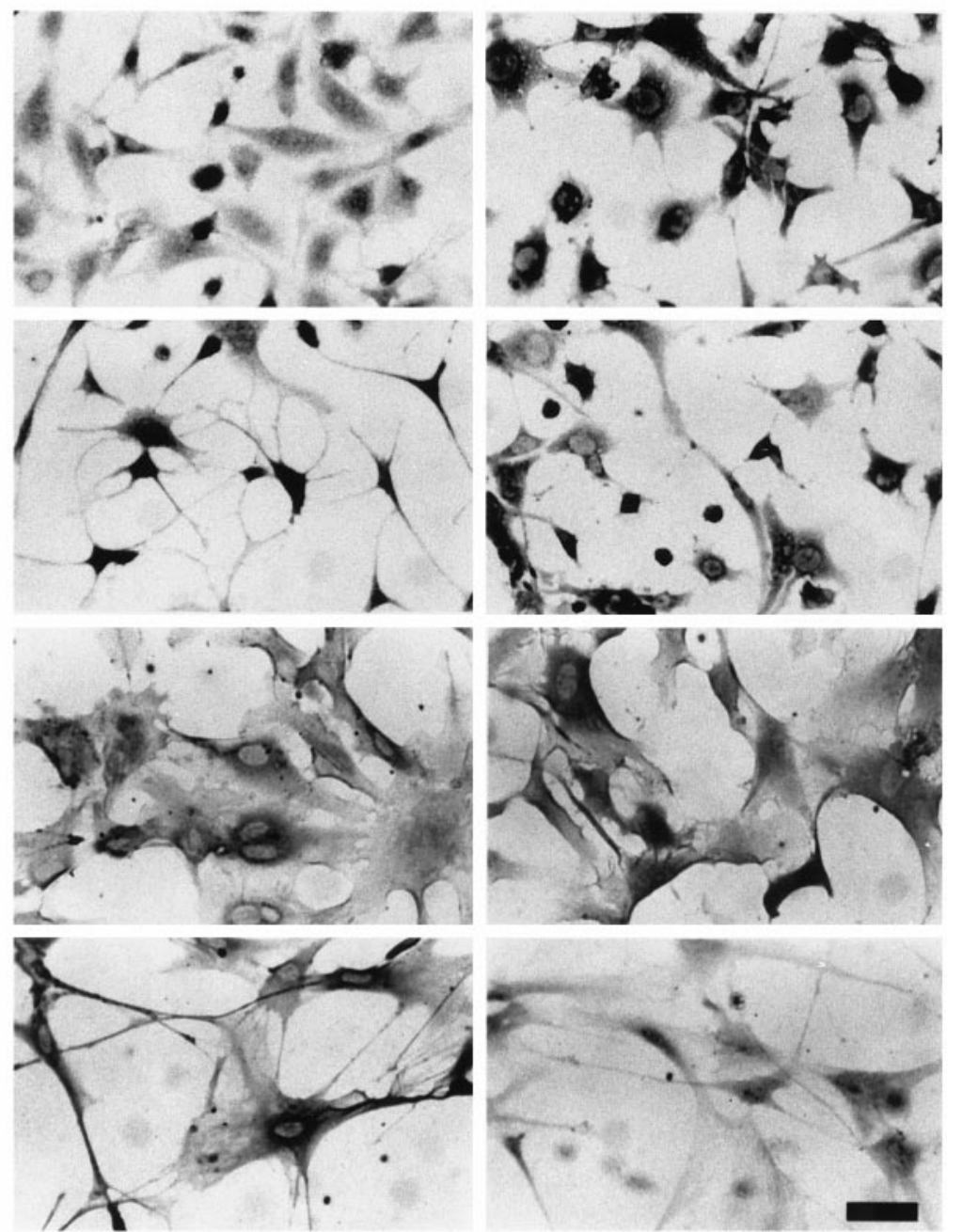

Figure 6. sHSP immunoreactivity in cultured glial cells exposed to chemical ischemia $(C I)$. After exposure to CI followed by 24 hr recovery, both HSP27- and $\alpha \mathrm{BC}$-immunoreactivity were increased with no distinct morphological change. The presence of $10 \mu \mathrm{M}$ isoproterenol (Iso) increased HSP27 immunoreactivity, whereas $\alpha \mathrm{BC}$ immunoreactivity was slightly decreased. Note the morphological change of HSP27-positive cells from an epithelial-like form to a stellate process-bearing form. Scale bar, $100 \mu \mathrm{m}$.

ized in neuronal perikarya (Fig. $8 A, C$ ), which was confirmed by double staining with the neuronal marker $200 \mathrm{kDa}$ neurofilament (data not shown). $\beta_{1} \mathrm{AR}$ - and $\beta_{2} \mathrm{AR}$-positive neurons were widely but heterogeneously distributed among brain regions such as the cerebral cortical layers, the thalamus, and the hippocampus. In the cerebral cortex, the cingulate cortex and the piriform cortex had a number of cells with moderate to strong immunoreactivity for both $\beta_{1} \mathrm{AR}$ and $\beta_{2} \mathrm{AR}$. Some astrocytic processes were also lightly stained for $\beta_{1} \mathrm{AR}$ (Fig. $8 B$ ) or $\beta_{2} \mathrm{AR}$ (Fig. $8 D$ ) in the controls. These $\beta_{1} \mathrm{AR}$ - or $\beta_{2} \mathrm{AR}$-positive astrocytic processes were frequently observed in proximity to $\beta_{1} \mathrm{AR}$ - or $\beta_{2} \mathrm{AR}$ positive neurons, although weak immunoreactivity was occasionally found in astrocytes located in the white matter. After focal ischemia, reactive astrocytes showed intense $\beta_{2}$ AR-like immunoreactivity. Both cell body and processes were stained for $\beta_{2} \mathrm{AR}$ (Fig. 8G,H). $\beta_{1}$ AR-like immunoreactivity was also increased but less apparent compared with $\beta_{2} \mathrm{AR}$-like immunoreactivity in reactive astrocytes (Fig. $8 E, F$ ).

\section{Effect of $\beta$ AR activation on cell proliferation of glial cells}

Incubation with $\mathrm{dBcAMP}$ or isoproterenol decreased the number of cultured cells in a concentration-dependent manner, as detected by MTT assay. Application of $1 \mathrm{~mm} \mathrm{dBcAMP}$ to either C6 cells or cultured astrocytes resulted in an $\sim 50 \%$ decrease in cell number compared with nontreated control cultures. The presence of $10 \mu \mathrm{M}$ isoproterenol also reduced cell number by $\sim 70 \%$ in both types of cells. To determine whether the observed decrease in cell number was caused by the inhibition of proliferation or the loss of cellular viability, trypan blue exclusion assay was performed. Approximately $98 \%$ of cells were trypan blue-negative in nontreated control cultures, and treatment with either dBcAMP or isoproterenol did not significantly change the number of trypan blue-positive cells at low concentrations. Although the viability of cells was slightly but significantly decreased at high concentrations (5 mM dBcAMP or $100 \mu \mathrm{M}$ isoproterenol), $>90 \%$ of cells were still viable (Fig. 9). These results indicate that $\beta A R$ activation and 
A

BARK1 C(S) $\quad$ Is(S)
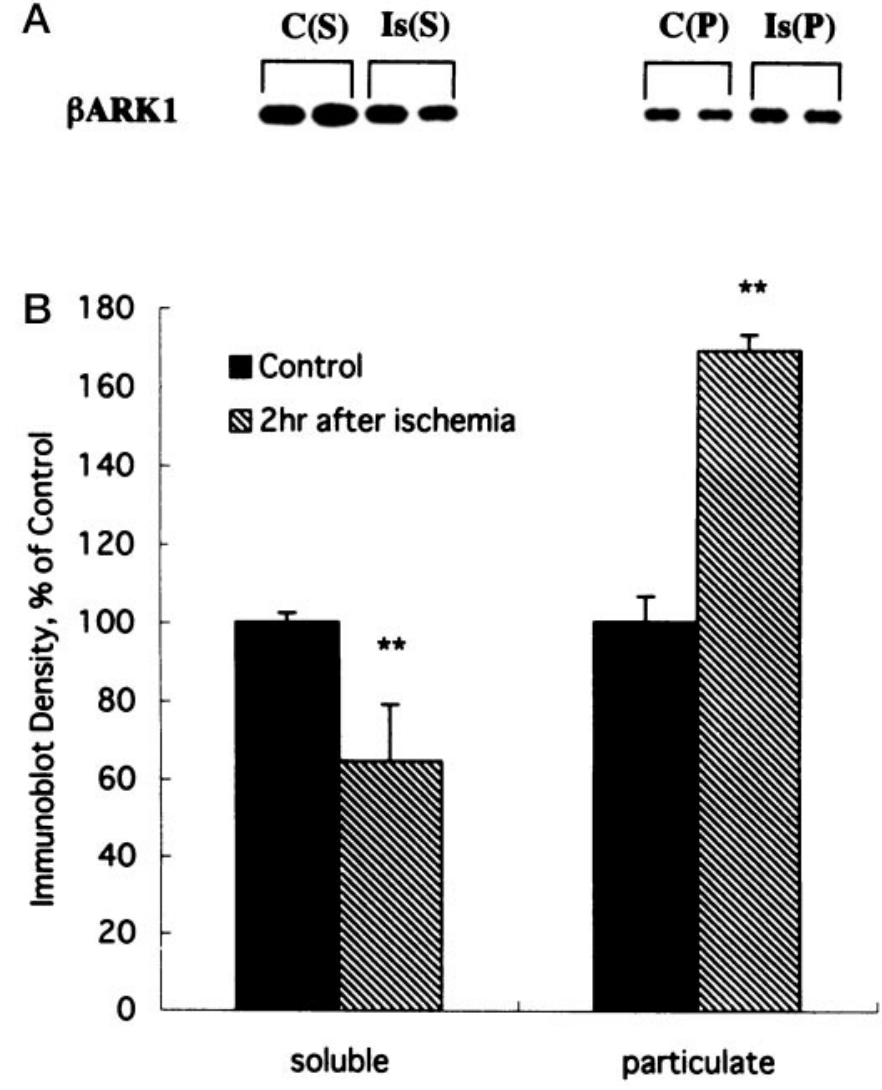

Figure 7. Translocation of $\beta \mathrm{ARK}$ in the early phase of ischemia. Homogenates from sham-control or ischemic hemispheres were centrifuged at $100,000 \times g$ for $60 \mathrm{~min}$. The pellet contained the particulate fraction $(P)$, and the supernatant contained the soluble fraction $(S)$. Equal amounts of protein $(20 \mu \mathrm{g})$ from each fraction were assayed by immunoblotting using the anti-GRK2 antibody (top panel), and densitometric analysis was performed for quantification (bottom panel). At $2 \mathrm{hr}$ after ischemia $(I s)$, the content of $\beta A R K$ in the soluble fraction was significantly decreased, whereas that in the particulate fraction was increased compared with sham-controls $(C)$. Data represent mean $\pm \operatorname{SEM}(n=4)$. $* * p<0.01$ versus control, using Student's $t$ test.

intracellular cAMP accumulation inhibit glial cell proliferation with little change in cellular viability.

\section{DISCUSSION}

Several classes of the HSP family are synthesized in the CNS in response to ischemic injury (Wagstaff et al., 1996). The present study has demonstrated the marked induction of HSP27 in reactive astrocytes surrounding the infarct lesion that persisted until day 7. HSP70 expression, which is localized mainly in neurons, has been shown previously to decrease progressively from $3 \mathrm{~d}$ after ischemia in the same animal model (Kato et al., 1995), indicating that HSP27 may play a role in the chronic astroglial response to ischemic stress. HSP27 is known to be phosphorylated at two serine residues (Landry et al., 1992), which is essential for its protective function against stress stimuli (Lavoie et al., 1995; Huot et al., 1996), although the precise role of the phosphorylation remains unclear. Our results showed that the signaling pathway of HSP27 phosphorylation was continuously activated until day 7. The levels of several cytokines that can phosphorylate HSP27 have been shown to be elevated after focal ischemia (Buttini et al., 1994; Liu et al., 1994). It is possible that exogenous factors produced by neighboring cells such as micro- glia or by reactive astrocytes itself phosphorylate HSP27 to regulate its function.

In striking contrast to the marked induction of HSP27, the expression of $\alpha \mathrm{BC}$, another sHSP, remained at low levels, and a discrepancy between the expression of these two sHSPs was observed. Kato et al. (1994) have demonstrated that global ischemia induced HSP27 but that the levels of $\alpha \mathrm{BC}$ were not changed, whereas an increase in $\alpha \mathrm{BC}$ as well as HSP27 has been reported in the brains of patients with Alzheimer's disease and Alexander's disease (Iwaki et al., 1993; Shinohara et al., 1993; Renkawek et al., 1994b). Moreover, cultured astrocytes have been shown to increase $\alpha \mathrm{BC}$ as well as HSP27 in response to several stress stimuli (Head et al., 1994). It seems likely that the differential expression of the two sHSPs was characteristic of reactive astrocytes after ischemic injury.

The characteristics of reactive astrocytes are their morphology, including hypertrophy of cell bodies, nuclei, and numerous thicker processes, and an elevated expression of GFAP (Norton et al., 1992). Hyperplasia is thought to be another hallmark of reactive astrogliosis, although this may reflect a minor part of glial reaction (Cavanagh, 1970; Latov et al., 1979; Miyake et al., 1988; Takamiya et al., 1988; Topp et al., 1989). Astrogliosis is usually assumed to be a stereotypic response of astrocytes to insult. Recent studies, however, have demonstrated the biochemical and functional heterogeneity of reactive astrocytes depending on the location or the kind of injury (Norton et al., 1992; Hoke and Silver, 1994; Schroeter et al., 1995; Hill et al., 1996). A variety of the substances, such as neurotransmitters, serum factors, and cytokines may influence the astroglial response. Our study showed that cultured glial cells exposed to ischemic stress increased the expression of both HSP27 and $\alpha \mathrm{BC}$ simultaneously, unlike astrocytes in vivo. We speculated that the expression of sHSPs induced by ischemia in vivo is modulated by additional factors.

Previous studies using a microdialysis technique have revealed that extracellular noradrenaline concentration is transiently increased after brain ischemia (Globus et al., 1989; Gustafson et al., 1991). The source of noradrenaline was suggested to be a release from the nerve terminals under ischemic conditions (Santos et al., 1996). $\beta A R$, one of the targets of endogenous noradrenaline, is widely expressed within the CNS (Alexander et al., 1975), including astrocytes (Salm and McCarthy, 1992). This is confirmed by our findings that the both $\beta_{1} \mathrm{AR}$ - and $\beta_{2} \mathrm{AR}$-like immunoreactivities were localized in not only neurons but also astrocytes in vivo. Recent studies have provided evidence that $\beta$ AR plays an important role in developing reactive gliosis. Optic nerve crush increased $\beta_{2} \mathrm{AR}$ in astrocytes (Mantyh et al., 1995), and inf usion of a $\beta \mathrm{AR}$ antagonist attenuated the hypertrophic change and proliferation of astrocytes (Hodges Savola et al., 1996). A $\beta A R$ antagonist also suppressed the hypertrophy and an increase in GFAP after sciatic nerve injury (Sutin and Griffith, 1993). Our results demonstrated the translocation of $\beta A R K 1$ in the early phase of ischemia, suggesting that $\beta A R$ was stimulated in the ischemic hemispheres. Additionally, $\beta$ AR-like immunoreactivity increased in reactive astrocytes. An increase in $\beta_{2} \mathrm{AR}$-like immunoreactivity was more evident compared with $\beta_{1}$ AR-like immunoreactivity, which is consistent with the previous findings (Sutin and Shao, 1992; Mantyh et al., 1995). Extracellular noradrenaline is thought to rapidly decrease after reperfusion, whereas overexpression of HSP27 was observed till day 7. The altered $\beta$ AR expression in reactive astrocytes was likely to contribute to the prolonged overexpression of HSP27. Therefore, we next studied 

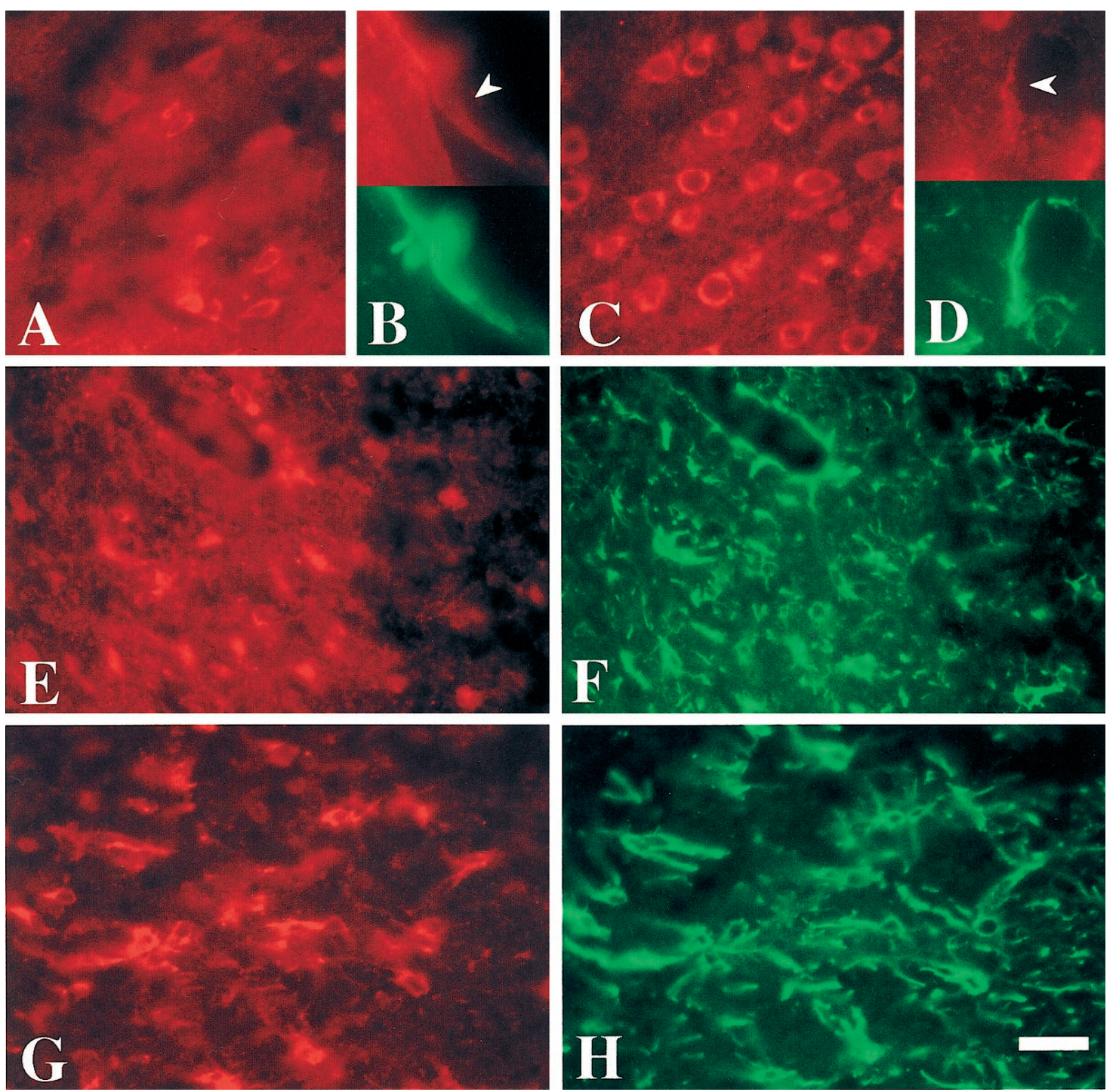

Figure 8. $\beta$ AR-like immunoreactivity in the rat brain. Double-fluorescence immunolabeling for GFAP $\left(B, D, F, H\right.$; FITC), $\beta_{1}$ AR $(A, B, E$; TRITC), and $\beta_{2} \mathrm{AR}\left(C, D, G\right.$; TRITC). Both $\beta_{1} \mathrm{AR}-(A)$ and $\beta_{2} \mathrm{AR}$-like immunoreactivities $(C)$ were predominantly localized in neuronal perikarya in the controls. Some processes (arrowhead) that were lightly stained for $\beta_{1} \mathrm{AR}(B)$ or $\beta_{2} \mathrm{AR}(D)$ in the controls corresponded to GFAP labeling. In the ischemic hemisphere, reactive astrocytes showed intense $\beta_{2} \mathrm{AR}$-like immunoreactivity. Both cell body and processes were stained for $\beta_{2} \mathrm{AR}(G, H)$. $\beta_{1} \mathrm{AR}$-like immunoreactivity was also increased but less apparent compared with $\beta_{2} \mathrm{AR}$-like immunoreactivity in reactive astrocytes $(E, F)$. Scale bar (in $H$ ): $A$, $C$, $E-H, 70 \mu \mathrm{m} ; B, D, 25 \mu \mathrm{m}$.

whether $\beta$ AR can regulate the expression of sHSPs in cultured glial cells.

Primary astrocytes expressed both sHSPs under standard culture conditions, whereas astrocytes showed no sHSP immunoreactivity in the controls in vivo. One possible explanation for this difference can be attributed to the developmental stage, because our preliminary results showed that sHSPs were abundantly expressed in embryonic brains but sharply decreased to the same level as in adult brains after birth. After chemical ischemia, both sHSPs were induced simultaneously. Isoproterenol, a $\beta$ AR agonist, increased HSP27 but suppressed $\alpha \mathrm{BC}$, mimicking the expression of sHSPs in reactive astrocytes in vivo. The effect was commonly observed in both C6 cells and primary astrocytes with or without ischemia, but the suppressive effect on $\alpha \mathrm{BC}$ expression in primary astrocytes was more potent than in $\mathrm{C} 6$ cells. The difference may be because the expression of $\beta \mathrm{AR}$ in $\mathrm{C} 6$ cells was low compared to that in astrocytes. It has been reported that $\beta$ AR-induced cAMP accumulation in C6 cells is sometimes lost during passage (Gubits et al., 1992). The effect of isoproterenol was mediated via $\beta \mathrm{AR}$-adenylate cyclase coupling because $\mathrm{dB}$ cAMP had the same effect, and a $\beta A R$ antagonist reversed the effect. Although little is known about the functional diversity of HSP27 and $\alpha \mathrm{BC}$, the differential regulation of the expression of these two sHSPs has been reported. In astrocytes, tumor necrosis factor- $\alpha$ and hypertonic stress induced $\alpha \mathrm{BC}$ but not HSP27 (Head et al., 1994). The precise mechanism of the transcriptional regulation of these two sHSPs requires further study.

$\beta A R$ stimulation changed the shape of cultured cells from a fibrous to a stellate form accompanied by an increase in HSP27, raising the possibility that the morphological change of cultured cells requires overexpression of HSP27. The formation of reactive astrocytes in vivo seems to depend on the overexpression and reorganization of cytoskeletal proteins such as GFAP and actin (Abd El Basset and Fedoroff, 1997). Recent studies have revealed 
(A)
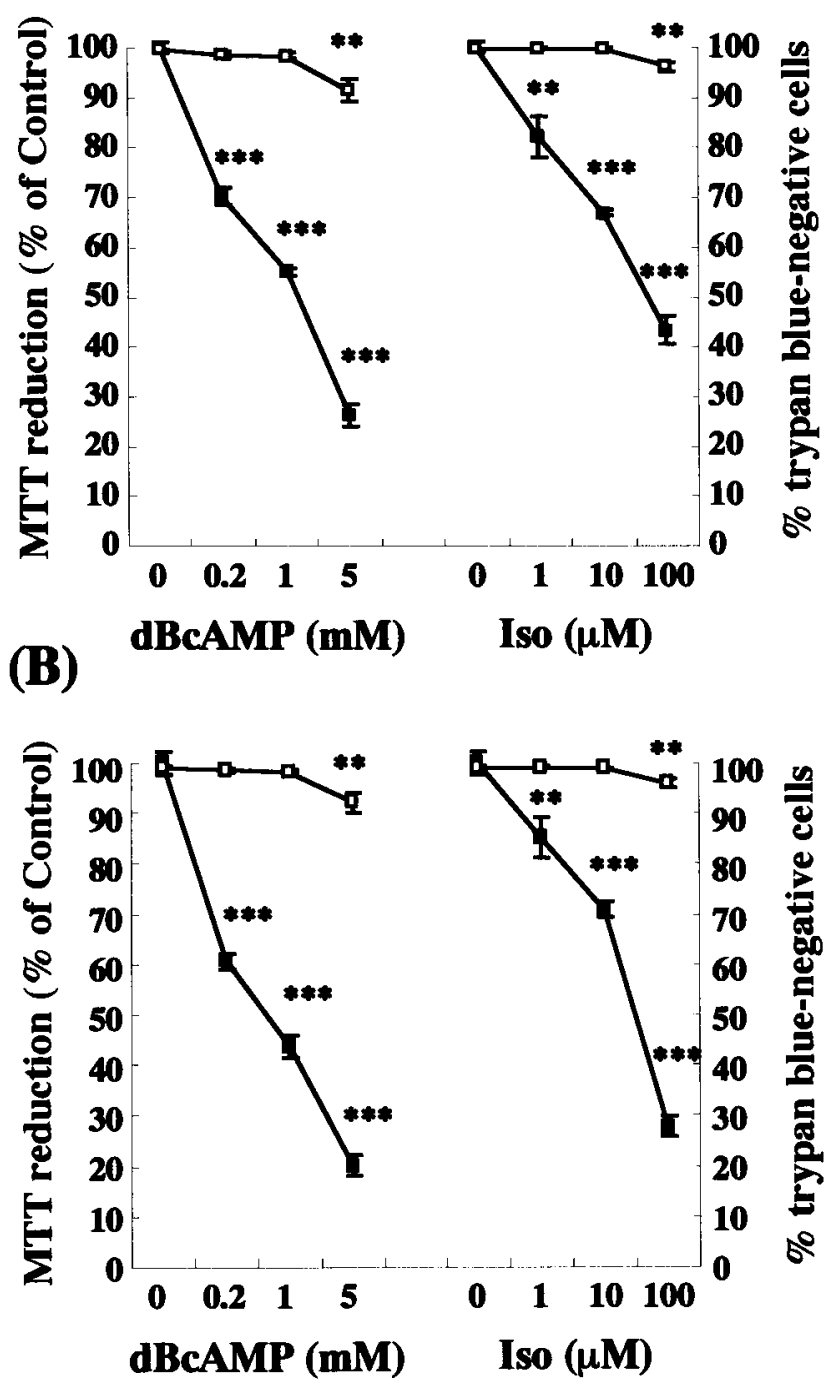

Figure 9. $\beta \mathrm{AR}$ stimulation suppressed glial cell proliferation with little change in viability. After $1 \mathrm{~d}$ culture, dBcAMP, isoproterenol (Iso), or vehicle was added, and incubation continued for another $3 \mathrm{~d}$ ( $A$, C6 cells) or for another $6 \mathrm{~d}$ with one media change ( $B$, primary astrocytes). Cell proliferation was measured using MTT assay (black squares, $n=6$ ), and cell viability was determined by trypan blue exclusion assay (white squares, $n=8)$. Both $\mathrm{dBcAMP}$ and Iso inhibited cell proliferation in a concentration-dependent manner, whereas the viability of cells was little affected. Data represent mean \pm SEM. ${ }^{* *} p<0.01 ;{ }^{* * *} p<0.001$ versus control, using Student's $t$ test.

that sHSP can modulate not only actin microfilament dynamics (Lavoie et al., 1993) but also GFAP assembly (Nicholl and Quinlan, 1994). $\beta A R$ activation was shown to increase the synthesis of GFAP (Segovia et al., 1994) and also to regulate GFAP assembly by the phosphorylation of their non- $\alpha$-helical head domains (McCarthy et al., 1985; Ralton et al., 1994). These findings suggest that $\beta$ AR activation and an increase in HSP27 may play an important role in cytoskeletal reorganization, accompanied by the formation of gliosis after ischemic injury. On the other hand, both $\mathrm{dBcAMP}$ and isoproterenol suppressed cell proliferation in vitro. Overexpression of HSP27 has also been shown to inhibit mitotic activity in several types of cells (Shakoori et al., 1992;
Spector et al., 1992; Mehlen et al., 1997). Thus, it is likely that $\beta \mathrm{AR}$ activation is not involved in the hyperplasia of astrocytes after insult. Schroeter et al. (1995) demonstrated that GFAPpositive astrocytes were widely distributed in the ipsilateral hemisphere but that vimentin-positive astrocytes were restricted to the peri-infarct area after focal ischemia and suggested that only vimentin-positive cells proliferated. The similar distribution of HSP27-positive astrocytes to GFAP-positive cells and of $\alpha \mathrm{BC}$ positive cells to vimentin-positive cells invites the speculation that $\alpha \mathrm{BC}$-positive astrocytes have different properties from the widely distributed HSP27-positive astrocytes.

In conclusion, the present study indicates that $\beta \mathrm{AR}$ activation may be involved in the morphological changes of reactive astrocytes accompanied by a modulation in sHSP expression. $\beta \mathrm{AR}$ activation has also been reported to increase the synthesis of several growth factors and the amyloid precursor proteins in astrocytes (Schwartz et al., 1994; Lee et al., 1997), suggesting that $\beta A R$ activation in astrocytes may affect the survival of neurons. The functional diversity between HSP27 and $\alpha \mathrm{BC}$ awaits future study, and clarification of what regulates the transformation of astrocytes to their reactive form will provide the chance for eventual therapeutic target after brain injury.

\section{REFERENCES}

Abd El Basset EM, Fedoroff S (1997) Upregulation of F-actin and $\alpha$-actinin in reactive astrocytes. J Neurosci Res 49:608-616.

Alexander RW, Davis JN, Lefkowitz RJ (1975) Direct identification and characterisation of $\beta$-adrenergic receptors in rat brain. Nature 258:437-440.

Arrigo AP (1995) Expression of stress gene during development. Neuropathol Appl Neurobiol 21:488-491.

Arrigo AP, Welch WJ (1987) Characterization and purification of the small 28,000-dalton mammalian heat shock protein. J Biol Chem 262:15359-15369.

Arrigo AP, Suhan JP, Welch WJ (1988) Dynamic changes in the structure and intracellular locale of the mammalian low-molecular-weight heat shock protein. Mol Cell Biol 8:5059-5071.

Arriza JL, Dawson TM, Simerly RB, Martin LJ, Caron MG, Snyder SH, Lefkowitz RJ (1992) The G-protein-coupled receptor kinases $\beta$ ARK1 and $\beta$ ARK2 are widely distributed at synapses in rat brain. J Neurosci 12:4045-4055.

Augusteyn RC, Koretz JF (1987) A possible structure for $\alpha$-crystallin. FEBS Lett 222:1-5.

Benndorf R, Hayess K, Ryazantsev S, Wieske M, Behlke J, Lutsch G (1994) Phosphorylation and supramolecular organization of murine small heat shock protein HSP25 abolish its actin polymerizationinhibiting activity. J Biol Chem 269:20780-20784.

Benovic JL, DeBlasi A, Stone WC, Caron MG, Lefkowitz RJ (1989) $\beta$-adrenergic receptor kinase: primary structure delineates a multigene family. Science 246:235-240.

Bradford MM (1976) A rapid and sensitive method for the quantitation of microgram quantities of protein utilizing the principle of protein-dye binding. Anal Biochem 72:248-254.

Buttini M, Sauter A, Boddeke HW (1994) Induction of interleukin-1 $\beta$ mRNA after focal cerebral ischaemia in the rat. Mol Brain Res 23:126-134.

Cavanagh JB (1970) The proliferation of astrocytes around a needle wound in the rat brain. J Anat 106:471-487.

Globus MY, Busto R, Dietrich WD, Martinez E, Valdes I, Ginsberg MD (1989) Direct evidence for acute and massive norepinephrine release in the hippocampus during transient ischemia. J Cereb Blood Flow Metab 9:892-896.

Gorg A, Postel W, Gunther S (1988) The current state of twodimensional electrophoresis with immobilized $\mathrm{pH}$ gradients. Electrophoresis 9:531-546.

Gubits RM, Yu H, Casey G, Munell F, Vitek MP (1992) Altered genetic response to $\beta$-adrenergic receptor activation in late passage $\mathrm{C} 6$ glioma cells. J Neurosci Res 33:297-305.

Gustafson I, Westerberg EJ, Wieloch T (1991) Extracellular brain cor- 
tical levels of noradrenaline in ischemia: effects of desipramine and postischemic administration of idazoxan. Exp Brain Res 86:555-561.

Head MW, Corbin E, Goldman JE (1994) Coordinate and independent regulation of $\alpha$ B-crystallin and hsp27 expression in response to physiological stress. J Cell Physiol 159:41-50.

Hill SJ, Barbarese E, McIntosh TK (1996) Regional heterogeneity in the response of astrocytes following traumatic brain injury in the adult rat. J Neuropathol Exp Neurol 55:1221-1229.

Hodges Savola C, Rogers SD, Ghilardi JR, Timm DR, Mantyh PW (1996) $\beta$-adrenergic receptors regulate astrogliosis and cell proliferation in the central nervous system in vivo. Glia 17:52-62.

Hoke A, Silver J (1994) Heterogeneity among astrocytes in reactive gliosis. Perspect Dev Neurobiol 2:269-274.

Huot J, Houle F, Spitz DR, Landry J (1996) HSP27 phosphorylationmediated resistance against actin fragmentation and cell death induced by oxidative stress. Cancer Res 56:273-279.

Iwaki T, Wisniewski T, Iwaki A, Corbin E, Tomokane N, Tateishi J, Goldman JE (1992) Accumulation of $\alpha$ B-crystallin in central nervous system glia and neurons in pathologic conditions. Am J Pathol 140:345-356

Iwaki T, Iwaki A, Tateishi J, Sakaki Y, Goldman JE (1993) $\alpha$ B-crystallin and 27 -kd heat shock protein are regulated by stress conditions in the central nervous system and accumulate in Rosenthal fibers. Am J Pathol 143:487-495.

Jakob U, Gaestel M, Engel K, Buchner J (1993) Small heat shock proteins are molecular chaperones. J Biol Chem 268:1517-1520.

Kato H, Liu Y, Kogure K, Kato K (1994) Induction of $27-\mathrm{kDa}$ heat shock protein following cerebral ischemia in a rat model of ischemic tolerance. Brain Res 634:235-244.

Kato H, Kogure K, Liu XH, Araki T, Kato K, Itoyama Y (1995) Immunohistochemical localization of the low molecular weight stress protein HSP27 following focal cerebral ischemia in the rat. Brain Res 679:1-7.

Klemenz R, Frohli E, Steiger RH, Schafer R, Aoyama A (1991) $\alpha$ B-crystallin is a small heat shock protein. Proc Natl Acad Sci USA 88:3652-3656.

Landry J, Chretien P, Laszlo A, Lambert H (1991) Phosphorylation of HSP27 during development and decay of thermotolerance in Chinese hamster cells. J Cell Physiol (Lond) 147:93-101.

Landry J, Lambert H, Zhou M, Lavoie JN, Hickey E, Weber LA, Anderson CW (1992) Human HSP27 is phosphorylated at serines 78 and 82 by heat shock and mitogen-activated kinases that recognize the same amino acid motif as S6 kinase II. J Biol Chem 267:794-803.

Latov N, Nilaver G, Zimmerman EA, Johnson WG, Silverman AJ, Defendini R, Cote L (1979) Fibrillary astrocytes proliferate in response to brain injury: a study combining immunoperoxidase technique for glial fibrillary acidic protein and radioautography of tritiated thymidine. Dev Biol 72:381-384.

Lavoie JN, Hickey E, Weber LA, Landry J (1993) Modulation of actin microfilament dynamics and fluid phase pinocytosis by phosphorylation of heat shock protein 27. J Biol Chem 268:24210-24214.

Lavoie JN, Lambert H, Hickey E, Weber LA, Landry J (1995) Modulation of cellular thermoresistance and actin filament stability accompanies phosphorylation-induced changes in the oligomeric structure of heat shock protein 27. Mol Cell Biol 15:505-516.

Lee RKK, Araki W, Wurtman RJ (1997) Stimulation of amyloid precursor protein synthesis by adrenergic receptors coupled to cAMP formation. Proc Natl Acad Sci USA 94:5422-5426.

Liu T, Clark RK, McDonnell PC, Young PR, White RF, Barone FC, Feuerstein GZ (1994) Tumor necrosis factor- $\alpha$ expression in ischemic neurons. Stroke 25:1481-1488.

Lutsch G, Vetter R, Offhauss U, Wieske M, Grone HJ, Klemenz R, Schimke I, Stahl J, Benndorf R (1997) Abundance and location of the small heat shock proteins HSP25 and $\alpha$ B-crystallin in rat and human heart. Circulation 96:3466-3476.

Mantyh PW, Rogers SD, Allen CJ, Catton MD, Ghilardi JR, Levin LA, Maggio JE, Vigna SR (1995) $\beta$ 2-adrenergic receptors are expressed by glia in vivo in the normal and injured central nervous system in the rat, rabbit, and human. J Neurosci 15:152-164.

McCarthy KD, de Vellis J (1980) Preparation of separate astroglial and oligodendroglial cell cultures from rat cerebral tissue. J Cell Biol 85:890-902.

McCarthy KD, Prime J, Harmon T, Pollenz R (1985) Receptormediated phosphorylation of astroglial intermediate filament proteins in cultured astroglia. J Neurochem 44:723-730.
Mehlen P, Mehlen A, Godet J, Arrigo AP (1997) hsp27 as a switch between differentiation and apoptosis in murine embryonic stem cells. J Biol Chem 272:31657-31665.

Mehlen P, Schulze Osthoff K, Arrigo AP (1996) Small stress proteins as novel regulators of apoptosis. Heat shock protein 27 blocks Fas/APO-1and staurosporine-induced cell death. J Biol Chem 271:16510-16514.

Miyake T, Hattori T, Fukuda M, Kitamura T, Fujita S (1988) Quantitative studies on proliferative changes of reactive astrocytes in mouse cerebral cortex. Brain Res 451:133-138.

Mosmann T (1983) Rapid colorimetric assay for cellular growth and survival: application to proliferation and cytotoxicity assays. J Immunol Methods 65:55-63.

Nagasawa H, Kogure K (1989) Correlation between cerebral blood flow and histologic changes in a new rat model of middle cerebral artery occlusion. Stroke 20:1037-1043.

Nicholl ID, Quinlan RA (1994) Chaperone activity of $\alpha$-crystallins modulates intermediate filament assembly. EMBO J 13:945-953.

Norton WT, Aquino DA, Hozumi I, Chiu FC, Brosnan CF (1992) Quantitative aspects of reactive gliosis: a review. Neurochem Res 17:877-885.

Ralton JE, Lu X, Hutcheson AM, Quinlan RA (1994) Identification of two N-terminal non- $\alpha$-helical domain motifs important in the assembly of glial fibrillary acidic protein. J Cell Sci 107:1935-1948.

Renkawek K, de Jong WW, Merck KB, Frenken CW, van Workum FP, Bosman GJ (1992) $\alpha$ B-crystallin is present in reactive glia in Creutzfeldt-Jakob disease. Acta Neuropathol Berl 83:324-327.

Renkawek K, Bosman GJ, de Jong WW (1994a) Expression of small heat-shock protein hsp 27 in reactive gliosis in Alzheimer disease and other types of dementia. Acta Neuropathol Berl 87:511-519.

Renkawek K, Voorter CE, Bosman GJ, van Workum FP, de Jong WW (1994b) Expression of $\alpha$ B-crystallin in Alzheimer's disease. Acta Neuropathol Berl 87:155-160.

Saklatvala J, Kaur P, Guesdon F (1991) Phosphorylation of the small heat-shock protein is regulated by interleukin 1, tumour necrosis factor, growth factors, bradykinin and ATP. Biochem J 277:635-642.

Salm AK, McCarthy KD (1992) The evidence for astrocytes as a target for central noradrenergic activity: expression of adrenergic receptors. Brain Res Bull 29:265-275.

Santos MS, Moreno AJ, Carvalho AP (1996) Relationships between ATP depletion, membrane potential, and the release of neurotransmitters in rat nerve terminals. An in vitro study under conditions that mimic anoxia, hypoglycemia, and ischemia. Stroke 27:941-950.

Schroeter M, Schiene K, Kraemer M, Hagemann G, Weigel H, Eysel UT, Witte OW, Stoll G (1995) Astroglial responses in photochemically induced focal ischemia of the rat cortex. Exp Brain Res 106:1-6.

Schwartz JP, Nishiyama N, Wilson D, Taniwaki T (1994) Receptormediated regulation of neuropeptide gene expression in astrocytes. Glia 11:185-190.

Segovia J, Lawless GM, Tillakaratne NJ, Brenner M, Tobin AJ (1994) Cyclic AMP decreases the expression of a neuronal marker (GAD67) and increases the expression of an astroglial marker (GFAP) in C6 cells. J Neurochem 63:1218-1225.

Shakoori AR, Oberdorf AM, Owen TA, Weber LA, Hickey E, Stein JL, Lian JB, Stein GS (1992) Expression of heat shock genes during differentiation of mammalian osteoblasts and promyelocytic leukemia cells. J Cell Biochem 48:277-287.

Shinohara H, Inaguma Y, Goto S, Inagaki T, Kato K (1993) $\alpha$ B crystallin and HSP28 are enhanced in the cerebral cortex of patients with Alzheimer's disease. J Neurol Sci 119:203-208.

Spector NL, Samson W, Ryan C, Gribben J, Urba W, Welch WJ, Nadler LM (1992) Growth arrest of human B lymphocytes is accompanied by induction of the low molecular weight mammalian heat shock protein (Hsp28). J Immunol 148:1668-1673.

Strasser RH, Benovic JL, Caron MG, Lefkowitz RJ (1986) $\beta$-agonistand prostaglandin E1-induced translocation of the $\beta$-adrenergic receptor kinase: evidence that the kinase may act on multiple adenylate cyclase-coupled receptors. Proc Natl Acad Sci USA 83:6362-6366.

Sutin J, Griffith R (1993) $\beta$-adrenergic receptor blockade suppresses glial scar formation. Exp Neurol 120:214-222.

Sutin J, Shao Y (1992) Resting and reactive astrocytes express adrenergic receptors in the adult rat brain. Brain Res Bull 29:277-284.

Takamiya Y, Kohsaka S, Toya S, Otani M, Tsukada Y (1988) Immunohistochemical studies on the proliferation of reactive astrocytes and the 
expression of cytoskeletal proteins following brain injury in rats. Brain Res 466:201-210.

Topp KS, Faddis BT, Vijayan VK (1989) Trauma-induced proliferation of astrocytes in the brains of young and aged rats. Glia 2:201-211.

van Noort JM, van Sechel AC, Bajramovic JJ, el Ouagmiri M, Polman CH, Lassmann H, Ravid R (1995) The small heat-shock protein $\alpha$ B-crystallin as candidate autoantigen in multiple sclerosis [see comments]. Nature 375:798-801.

Varming T, Drejer J, Frandsen A, Schousboe A (1996) Characterization of a chemical anoxia model in cerebellar granule neurons using sodium azide: protection by nifedipine and MK-801. J Neurosci Res 44:40-46. Vornov JJ (1995) Toxic NMDA-receptor activation occurs during recovery in a tissue culture model of ischemia. J Neurochem 65:1681-1691. Wagstaff MJ, Collaco Moraes Y, Aspey BS, Coffin RS, Harrison MJ, Latchman DS, de Belleroche JS (1996) Focal cerebral ischaemia increases the levels of several classes of heat shock proteins and their corresponding mRNAs. Mol Brain Res 42:236-244.

Welch WJ (1985) Phorbol ester, calcium ionophore, or serum added to quiescent rat embryo fibroblast cells all result in the elevated phosphorylation of two 28,000-dalton mammalian stress proteins. J Biol Chem 260:3058-3062. 